\title{
Career Planning Education in Universities Based on Experiential
}

\author{
Teaching Mode \\ Liu Hui ${ }^{1, a^{*}}$, Liu Qingyu ${ }^{2, b}$ \\ ${ }^{1,2}$ Room 605,MingDe Building,University of Electronic Science and Technology of \\ China,Zhongshan institute \\ Shiqi District of Zhongshan City, Guangdong Province,China,528402 \\ a26364127@qq.com, b304476612@qq.com
}

Keywords: Experiential teaching, career planning education, curriculum design

Abstract. Experiential teaching model is an effective way to promote career planning teaching efficiency.This paper analyzes the necessity of experiential teaching in career planning education, discusses the teaching process in detail and then put forward the problems needed to be focus on in the teaching process. The purpose of this paper is to provide scientific reference for career planning education in colleges and universities and to promote college students' career planning consciousness and to improve the quality of talent training in colleges and universities.

In order to help undergraduate students' self-cognition,looking for their orientation,and giveing full play to their potential, various universities according to " college students' career development and employment guidance course teaching requirements " promulgated by the Ministry of Education in $2007^{[1]}$, have offered career planning related courses, but the teaching effect is not as perfect as expected.In this paper,the experiential teaching model is applied in career planning teaching and 'experience' is as a teaching strategy and center.Through interactive experience activities,we want to arouse the inner sense of career planning of college students, improve capacity of career planning, besides, provide a reference for career planning course teaching reform.

\section{Connotation of Experiential Career Planning Teaching}

Experiential teaching derived from experiential learning proposed in the 1940s. David Kolb raised experiential learning styles model in 1984.which makes "positive experiment (doing) --investment experience (feeling) --reflection observation (observation) --summary (thinking)" as a systematic integrated learning process. ${ }^{[2]}$

Experiential career planning teaching means, in the process of career planning education in order to achieve objectives, starting from the teaching need, introducing or creating career related 
specific situations first,teachers choose the appropriate guide and problems, and lead students to participate in the activities to stimulate students' emotional experience.At the end of activities,students think deeply and share their feelings and experiences , then teachers give some comments to help students correctly understanding the teaching content, forming career planning consciousness, promoting employment career planning ability,planing their career development.

\section{Career Planning Curriculum Design Based on Experiential Teaching Mode}

Experiential career planning course begins with experience, through rethinking and sharing of students, and then with the help of teacher's summary, sublimation, and ultimately internalizes into the students' career planning awareness, to help students get the ability of solving the problem of career planning.

\section{Design and guide of Career Experience Activities}

Experiential teaching mode relies on activities,games,situations and cases well-designed according to teaching contents and teaching aims to guide students to actively participate in.Under the guiding,students may comprehend their personality, interests, ability and career decision-making process profoundly.In order to stimulate students' enthusiasm and interest, and to ensure the effectiveness of the teaching, teachers should guide students to understand the meaning of the activities, master the rules and methods of activities, and clear the activity process.Systematic activity process and scientific guide words are important premise to ensure the effect of experiential teaching. The teaching mode requires higher teachers' personal ability and professional quality.

\section{Participate in Career Experience Activities}

In experiential teaching mode,students as the main body, should participate in all kinds of career experiential activities personally or as a group under teachers' guidance according to requirements of the activities. They also have to observe others' statements and actions in the activities, stimulate personal experience, find problems and explore methods to solve the problem actively, so as to improve the ability of self-observation, self-reflection, self-analysis .

\section{Thinking and Sharing of Career Experience Activities}

Career experience activity is a process of problem consciousness training. Teachers,participating in experience activities as a conductor and spectator,observe student's 
reaction and put forward some questions about career planning and development.Participants share their experiences, perceptions and insights into the experience.Reflections on career experiences activities can prompt students to think about further career deeply and clear self-awareness of career planning.It is helpful for cultivating students' teamwork consciousness and promoting the development of career in the future to share and discuss methods to solve career planing related problems.

\section{Internalization and Sublimation of Career Experience Activities}

The purpose of experiential career planning teaching is to internalize the rigid career planning theory knowledge into students' self-planning consciousness by more vivid teaching methods, and then to improve students' career planning ability.In order to achieve this goal, teachers should guide students to participate in extracurricular practice actively in addition to rise student's real experience, confusion and so on to the theoretical level.The extracurricular practice includes visiting enterprises,participating in occupation planning competitions and so on. Through the close connect between students and enterprises and society,students can practice and rationally use the knowledge they have learned.Learning through practice,forming a new understanding, and then applying it to practice is a virtuous cycle by which to internalize career planning knowledge in depth.

\section{Problems should be payed attention to in Experiential Career Planning Teaching}

\section{Problems should be payed attention to by teachers}

First,teachers should take full consideration of the requirements of the teaching objectives when design experiential activities , and follow the principle of establishing career planning awareness and training vocational planning ability .Second,the design of instructions and the setting of problems in experiential activities should be simple and clear and be strong pertinence and directive, because they are closely related to teaching contents. Third,teachers should pay attention to students' individual differences and carry out more in-depth personalized guidance and services

for special students in time.Forth, teachers should take into account the interest and the complexity of activities,meanwhile they have to actively ask questions to the students, and seek for feedback.information.

\section{Problems should be payed attention to by students}

First of all,students should prepare lessons before class, think more for purposefully study. 
Secondly,students should take part in inside and outside experiential activities actively under teachers' guidance and provide feedback information. Experience is a process of communication. Only when the participants think and share in time, the purpose of learning. can be achieved.

Experiential teaching mode of career planning courses can improve the ability of career planning and practice through experiential activities..It is a trend of career planning education development for colleges and universities to establish long-term mechanism of systematic experiential teaching mode.

\section{Acknowledgment}

This work is supported by University of Electronic Science and Technology of China,Zhongshan Institute education teaching reform project in 2015 (No:JDJG2015004), all support is gratefully acknowledged.

\section{References}

[1]Information on http: //baike.baidu.com/view/3442602.htm.

[2]Guo Rongrong,Career Planning.Beijing,2009.

[3]Information on http://www.moe.edu.cn/publicfiles/business/htmlfiles/moe/moe_745/200802/11260.html.

[4]Le Xongrong, The instruction design study of career planning education by experiential teaching method in college.Shanghai,2008.

[5]FENG Shuo,An Analysis of Experience Teaching in the Education of Career Planing.Adult Education, (2010)63-64.

[6]Zhao Yuena; Xiong Tao,Office of Admission and Employment,Nanchang Institute of Technology.Journal of Nanchang Institute of Technology,(2013)88-91. 